\title{
Manufactures Animal Over-the-Counter Type A Drugs
}

National Cancer Institute

\section{Source}

National Cancer Institute. Manufactures Animal Over-the-Counter Type A Drugs. NCl

Thesaurus. Code C114892.

A business that makes non-prescription veterinary Type $A$ drugs which do not require a feed directive. 